\title{
ChemComm
}

\section{Peptide-based hydrogen sulphide-releasing gels $\dagger$}

\author{
Cite this: Chem. Commun., 2015, \\ 51,13131 \\ Received 15th June 2015, \\ Accepted 11th July 2015
}

Jennifer M. Carter, Yun Qian, Jeffrey C. Foster and John B. Matson*

DOI: $10.1039 / c 5 c c 04883 d$

www.rsc.org/chemcomm

An aromatic peptide amphiphile was designed for delivery of the signaling gas $\mathrm{H}_{2} \mathrm{~S}$. The peptide self-assembled in water into nanofibers that gelled upon charge screening. The non-toxic gel slowly released $\mathrm{H}_{2} \mathrm{~S}$ over 15 hours, and the presence of $\mathrm{H}_{2} \mathrm{~S}$ in endothelial cells was verified using a fluorescent $\mathrm{H}_{2} \mathrm{~S}$ probe.

Despite its reputation as a foul-smelling, toxic pollutant, hydrogen sulphide $\left(\mathrm{H}_{2} \mathrm{~S}\right)$ is a vital biological signaling gas (gasotransmitter) produced endogenously by various enzymes. ${ }^{1}$ Within the past few years, efforts devoted to studying the biological roles of $\mathrm{H}_{2} \mathrm{~S}$, the enzymes that make it, and its therapeutic potential have expanded rapidly, ${ }^{2}$ along with related efforts to improve its detection in vitro and in vivo. ${ }^{3}$ While many biological studies on $\mathrm{H}_{2} \mathrm{~S}$ are conducted using sulphide salts ( $\mathrm{NaHS}$ and $\mathrm{Na}_{2} \mathrm{~S}$ ), injections of aqueous sulphide solutions lead to a rapid surge of $\mathrm{H}_{2} \mathrm{~S}$ in the bloodstream followed by a rapid decline. To combat this uncontrolled delivery and more closely mimic the slow and sustained release of endogenous $\mathrm{H}_{2} \mathrm{~S}$, our group and others have reported on small molecules that release $\mathrm{H}_{2} \mathrm{~S}$ with controllable kinetics. ${ }^{4}$ However, despite this progress on small molecule $\mathrm{H}_{2} \mathrm{~S}$ donors, very few efforts have been made in the area of $\mathrm{H}_{2} \mathrm{~S}$-releasing materials. ${ }^{5}$

In addition to $\mathrm{H}_{2} \mathrm{~S}$, nitric oxide (NO) and carbon monoxide (CO) are also classified as gasotransmitters. The study of NO biology has benefitted greatly from NO-releasing materials, including polymers, gels, microparticles, and others. ${ }^{6}$ The localized release provided by these materials allows for sitespecific delivery of the gas, which minimizes the required dosage and off-target effects that can result from systemic NO administration. In fact, NO-releasing materials have been studied widely in preclinical animal models for various applications. ${ }^{7}$ Additionally, CO releasing materials have also been reported, although they have not yet reached the stage of animal models. ${ }^{8}$

Department of Chemistry and Macromolecules and Interfaces Institute, Virginia Tech, Blacksburg, VA, 24061, USA. E-mail: jbmatson@vt.edu

$\dagger$ Electronic supplementary information (ESI) available: UV-vis and fluorescence spectroscopy data, CMC plots, additional TEM, rheology, and $\mathrm{H}_{2}$ S-release data, experimental procedures, and characterization data for all new materials. See DOI: $10.1039 / \mathrm{c} 5 \mathrm{cc} 04883 \mathrm{~d}$
In contrast, few $\mathrm{H}_{2} \mathrm{~S}$-releasing materials have been prepared for potential use in therapy: two polymeric $\mathrm{H}_{2} \mathrm{~S}$ donors ${ }^{5}$ and one $\mathrm{H}_{2} \mathrm{~S}$-releasing metal-organic framework. ${ }^{9}$ While polymers and other nanoparticle drug delivery systems may be useful for targeting specific tissues through systemic administration, $\mathrm{H}_{2} \mathrm{~S}$-releasing gels that can be localized at a site of interest are better suited as injectable biomaterials capable of filling a cavity or encapsulating cells while delivering precise doses of $\mathrm{H}_{2} \mathrm{~S}$ to an area of interest.

We recently reported on a family of small molecule $\mathrm{H}_{2} \mathrm{~S}$ donors based on the $S$-aroylthiooxime (SATO) functional group, which releases $\mathrm{H}_{2} \mathrm{~S}$ in response to thiol functionality. ${ }^{4 e}$ SATOs are prepared by reaction of an $S$-aroyl thiohydroxylamine $\left(\mathrm{Ar}-\mathrm{C}(\mathrm{O}) \mathrm{S}-\mathrm{NH}_{2}\right.$ ) (SATHA) with an aldehyde or ketone. $\mathrm{H}_{2} \mathrm{~S}$ release is triggered by thiols such as cysteine, and release rates can be tuned by changing substituents on the SATHA ring, with half-lives of release in the range of 8-80 minutes.

In this report, we describe the preparation of a selfassembling peptide designed to form an $\mathrm{H}_{2} \mathrm{~S}$-releasing gel. Self-assembling peptide-based materials include a wide range of peptide motifs that form one-dimensional nanostructures in aqueous solution. ${ }^{10}$ Gel formation in the range of $0.5-2 \mathrm{wt} \%$ peptide can often be triggered by charge screening through physical entanglement of the extended nanostructures by $\mathrm{pH}$ changes or addition of salt. No chemical crosslinking is required, allowing for in situ gelation of the materials and shear-thinning behaviour. These qualities, along with their inherent biodegradability and minimal immunogenicity in most cases, make peptide-based gelators an attractive alternative to traditional polymeric hydrogels that require chemical crosslinking.

One class of self-assembling peptides is the aromatic peptide amphiphiles. ${ }^{11}$ Comprised of short oligopeptides with terminal aromatic components, these small molecule gelators can be designed to self-assemble in water into extended cylindrical micelles or nanofibers. ${ }^{12}$ The aromatic groups in aromatic peptide amphiphiles have traditionally served a structural role-none have included reactive groups designed to release a bioactive small molecule such as $\mathrm{H}_{2} \mathrm{~S}$. 


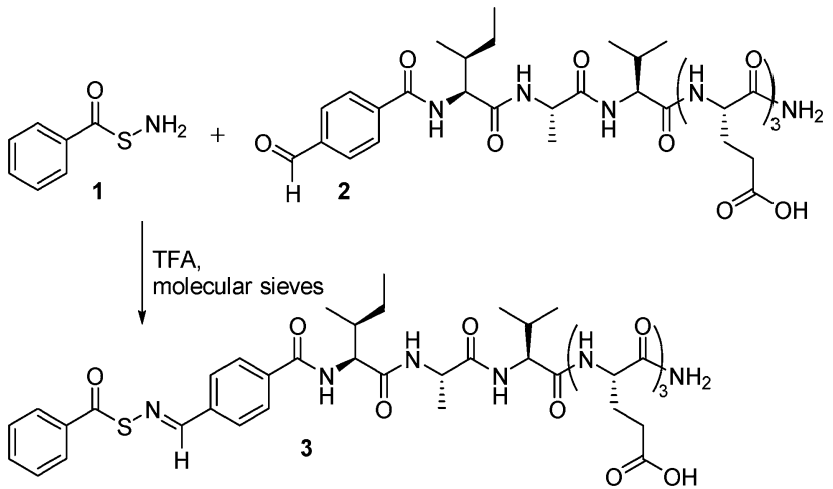

Scheme 1 Synthesis of SATO-containing aromatic peptide amphiphile 3 from SATHA 1 and aldehyde-containing peptide 2

Our design (Scheme 1) takes advantage of the inherent hydrophobicity of the SATO moiety to serve as both a structural component to drive self-assembly as well as a reactive functional group to release $\mathrm{H}_{2} \mathrm{~S}$. We envisioned that a SATO-functionalized aromatic peptide amphiphile could be designed to form 1-dimensional nanostructures capable of gelation. Additionally, we anticipated that the SATO functional groups would be buried in the hydrophobic core of the nanostructures, thereby limiting their access to the cysteine trigger required for decomposition and potentially extending their $\mathrm{H}_{2} \mathrm{~S}$-releasing capacity over hours to days.

The peptide design we envisioned included a hydrophobic SATO group attached to a short peptide that facilitated assembly into 1-dimensional nanostructures. In addition to aromatic stacking interactions in the nanofiber core, many aromatic peptide amphiphiles also rely on $\beta$-sheet-type hydrogen bonding along the long axis of the nanostructure to stabilize the cylindrical assembly. ${ }^{13}$ Toward this end, the peptide $\mathrm{IAVE}_{3}$ was synthesized under standard solid phase conditions using Fmoc chemistry. The IAV region was designed based on the propensity of certain residues to self-pair in $\beta$-sheets found in natural proteins. ${ }^{14}$ Ala, Ile, and Val exhibit the highest tendency to self-pair; therefore, we incorporated these amino acids into the peptide sequence. The EEE sequence was included to provide the necessary hydrophilic/hydrophobic balance to achieve amphiphilicity. 4-Formylbenzoic acid (FBA) was added on resin under the same conditions as typical amino acid couplings, giving the modified peptide FBA-IAVE 3 (2). Following cleavage and purification, peptide $\mathbf{2}$ was allowed to react with SATHA $\mathbf{1}$ in the presence of TFA, employing molecular sieves as a drying agent. Full conversion to peptide 3 was observed after 20 min by ${ }^{1} \mathrm{H}$ NMR spectroscopy, and precipitation of the reaction mixture into $\mathrm{CH}_{2} \mathrm{Cl}_{2}$ afforded peptide 3 , which was purified by preparative HPLC.

Transmission electron microscopy (TEM) was used to characterize the morphology of the self-assembled architecture of peptide 3 (Fig. 1A). Conventional TEM images revealed long, onedimensional nanostructures with an average diameter of $10 \mathrm{~nm}$. In contrast, TEM of peptide 2 (Fig. S5, ESI $\dagger$ ) revealed predominately small spherical micelles around $10 \mathrm{~nm}$ in diameter and some larger spherical structures around $50 \mathrm{~nm}$ in diameter. No onedimensional objects were observed.

Next, we examined whether peptide 3 was capable of forming a robust gel. Addition of aqueous $\mathrm{CaCl}_{2}$ solution to a $1 \mathrm{wt} \%$
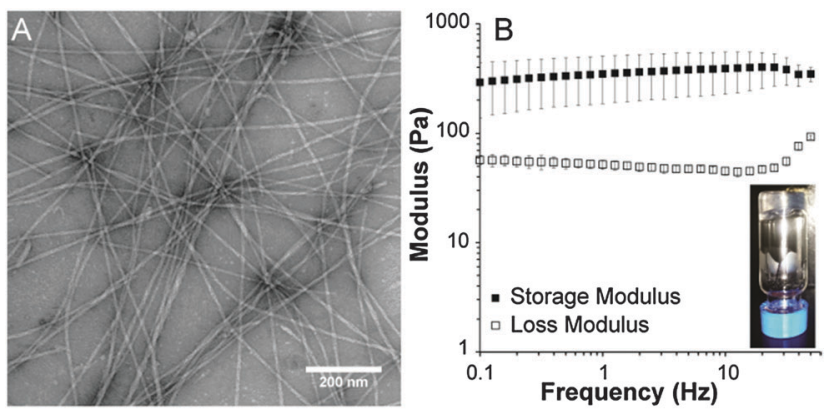

Fig. 1 (A) Conventional TEM image of peptide 3 cast from water (stained with $2 \%$ uranyl acetate). (B) Frequency sweep rheology of peptide 3 at $1 \mathrm{wt} \%$ in water gelled with $\mathrm{CaCl}_{2}$. Inset shows photograph of self-supporting gel.

solution of peptide 3 in water led to instantaneous gelation (Fig. 1B inset). As expected based on the TEM observations, addition of $\mathrm{CaCl}_{2}$ to a solution of peptide 2 did not result in gelation. The viscoelastic properties of the self-assembled peptide hydrogel prepared from a $1 \mathrm{wt} \%$ aqueous solution of peptide 3 were characterized by rheology (Fig. 1B). These experiments revealed that the gel was robust, with a storage modulus of $320 \mathrm{~Pa}$. Both the storage and loss moduli for peptide 3 remained steady independent of frequency up to $50 \mathrm{~Hz}$.

To evaluate the self-assembled structure of the nanofibers, we first measured the critical micelle concentrations (CMCs) of peptides 2 and 3 using the Nile red assay. Both peptides had CMC values of approximately $1 \mathrm{mg} \mathrm{mL}^{-1}$ (Fig. S6, ESI $\dagger$ ). Next, we characterized peptide 3 by circular dichroism (CD), IR, UV-Vis, and fluorescence spectroscopies. For all four characterization techniques, experiments were performed at a concentration below the CMC $\left(0.25 \mathrm{mg} \mathrm{mL}^{-1}\right)$, above the CMC $\left(10 \mathrm{mg} \mathrm{mL}^{-1}\right)$, and on the gel $\left(10 \mathrm{mg} \mathrm{mL}^{-1}\right.$ gelled with $\left.\mathrm{CaCl}_{2}\right)$.

Self-assembling peptides often have strong intermolecular hydrogen bonds that align with the long axis of the selfassembled nanofibers, typically taking on a $\beta$-sheet confirmation. This type of assembly results in a minimum at $220 \mathrm{~nm}$ and maximum at $190 \mathrm{~nm}$ in the CD spectrum. ${ }^{15}$ Peptide 3 exhibits a minimum at $199 \mathrm{~nm}$, which most resembles a random coil confirmation (Fig. 2A). Above the CMC, however, a minimum at $220 \mathrm{~nm}$ is observed. Unfortunately, the high concentration $\left(10 \mathrm{mg} \mathrm{mL}^{-1}\right)$ limited our ability to reliably collect data below $205 \mathrm{~nm}$, so the expected maximum at $190 \mathrm{~nm}$ could not be observed. A similar spectrum is observed upon gelation at $10 \mathrm{mg} \mathrm{mL}{ }^{-1}$, indicating that a $\beta$-sheet structure likely forms above the CMC and persists in the gel phase. Interestingly, a negative peak at $313 \mathrm{~nm}$ increases in intensity upon aggregation and gelation, likely indicating that the SATO chromophore resides in a chiral environment above the CMC of the peptide.

To further investigate the peptide secondary structure, IR spectroscopy was used to analyze the amide I band region (1600-1700 $\mathrm{cm}^{-1}$ ) of peptide 3. A strong absorption near $1630 \mathrm{~cm}^{-1}$ and a weaker absorption near $1680 \mathrm{~cm}^{-1}$ is typically observed when $\beta$-sheets are dominant. ${ }^{16}$ In contrast, absorptions for $\alpha$-helices and random coils are both located near $1650 \mathrm{~cm}^{-1}$. Below the CMC, an absorption peak centered at $1637 \mathrm{~cm}^{-1}$ with no secondary absorption near $1680 \mathrm{~cm}^{-1}$ is 

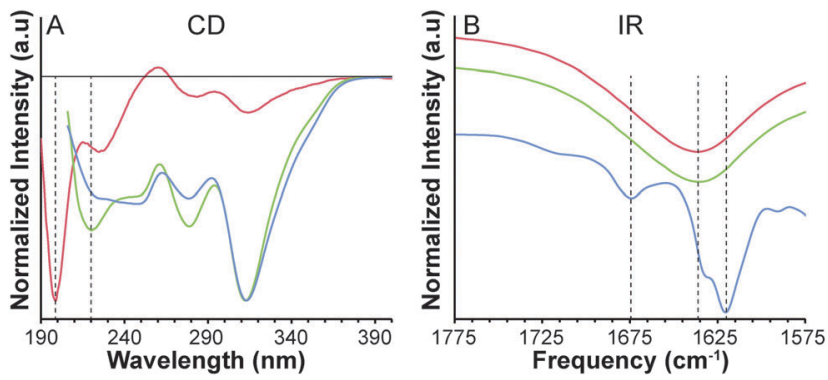

Fig. 2 Characterization of peptide 3 at $0.25 \mathrm{mg} \mathrm{mL}^{-1}$ (red), $10 \mathrm{mg} \mathrm{mL}^{-1}$ (green) and $10 \mathrm{mg} \mathrm{mL}^{-1}$ in gel form (blue). (A) CD spectroscopy normalized to largest peak. The solid horizontal line represents the 0 line; the vertical dashed lines highlight the peaks indicative of random coil (199 nm) and $\beta$-sheet $(220 \mathrm{~nm})$ structures. (B) IR spectroscopy with $y$-axes shifted for clarity. The vertical dashed lines designate the amide I absorptions indicative of random coil $\left(1637 \mathrm{~cm}^{-1}\right)$ and $\beta$-sheet $\left(1674\right.$ and $1620 \mathrm{~cm}^{-1}$ ) conformations.

observed for peptide 3. Above the CMC the absorption shifts to lower frequency at $1635 \mathrm{~cm}^{-1}$, but still without a secondary peak. Upon gelation, however, absorption peaks at $1620 \mathrm{~cm}^{-1}$ and $1674 \mathrm{~cm}^{-1}$ are present, indicative of a $\beta$-sheet structure.

UV-vis and fluorescence spectroscopy data (Fig. S7, ESI $\dagger$ ) show absorptions at around $320 \mathrm{~nm}$ and emissions with peaks near $470 \mathrm{~nm}$ at all concentrations. No substantial redshift in fluorescence upon aggregation or gelation is observed. Taken together, the spectroscopy data reveal that peptide 3 adopts a random coil conformation below the CMC and increases in $\beta$-sheet character above the CMC and upon gelation. Extensive aromatic stacking is not present in these aggregates but may play a minor role in self-assembly.

The rate of $\mathrm{H}_{2} \mathrm{~S}$ release from peptide 3 was measured using an $\mathrm{H}_{2} \mathrm{~S}$-selective microelectrode (Fig. 3). This method allows for real-time monitoring of the concentration of $\mathrm{H}_{2} \mathrm{~S}$ in solution. Peptide 3 in solution released $\mathrm{H}_{2} \mathrm{~S}$ more quickly than in gel form with an earlier peaking time (91 vs. $110 \mathrm{~min}$ ) and a higher peak concentration $(12.6 \mu \mathrm{M} v s .5 .5 \mu \mathrm{M})$. Additionally, a period of slow initial release was observed for the gel, in contrast to the soluble peptide that immediately began releasing $\mathrm{H}_{2} \mathrm{~S}$ upon addition of Cys. We attribute this induction period and overall slower release in gel form to limited diffusion of Cys into the gel. Importantly, measureable concentrations of $\mathrm{H}_{2} \mathrm{~S}$ were

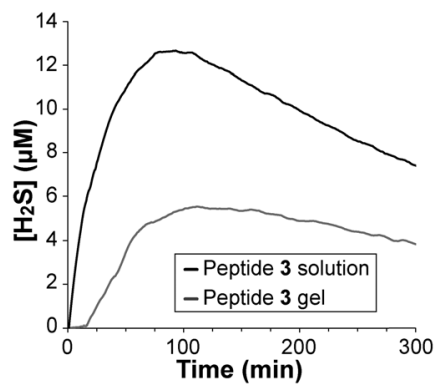

Fig. $3 \mathrm{H}_{2} \mathrm{~S}$ release from peptide $3(100 \mu \mathrm{M})$ in solution and as an aqueous gel (total of $100 \mu \mathrm{M}$ in peptide 3 ). Both experiments were run in PBS containing $1 \mathrm{mM}$ Cys.
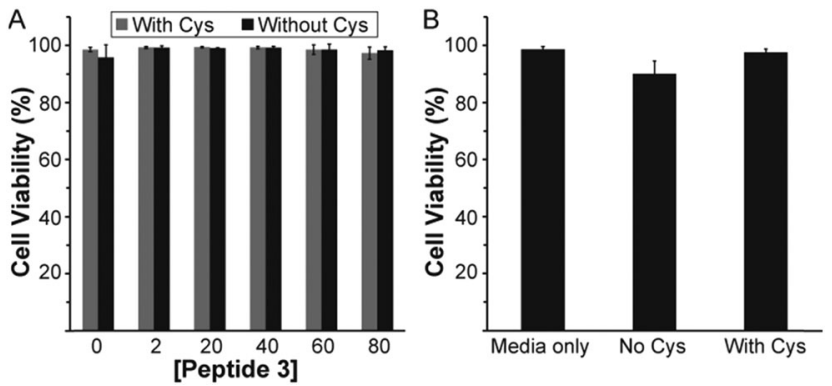

Fig. 4 Cytotoxicity of peptide 3 on endothelial cells in basal media with or without Cys (1 mM). (A) In solution. (B) As 1 wt\% aqueous gel. Viability was measured after $24 \mathrm{~h}$ by live/dead staining (calcein $\mathrm{AM}$ and ethidium homodimer).

released from the gel for over $15 \mathrm{~h}$ (Fig. S8, ESI $\dagger$ ). $\mathrm{No}_{2} \mathrm{~S}$ release was observed in the absence of Cys.

To assess whether peptide 3 could have potential use in vivo, a cytotoxicity study on mouse brain endothelial cells was conducted. Cytotoxicity of peptide 3 in solution was evaluated with and without Cys by measuring cell viability after $24 \mathrm{~h}$ (Fig. 4A). No toxicity was observed for the peptide 3 solution in either case up to $80 \mu \mathrm{M}$. Cytotoxicity of the peptide 3 gel at $1 \mathrm{wt} \%$ was also measured with and without Cys (Fig. 4B). Again, no significant toxicity was observed.

Lastly, $\mathrm{H}_{2} \mathrm{~S}$ release from peptide 3 in the presence of endothelial cells was analyzed using a turn-on fluorescent probe selective for $\mathrm{H}_{2} \mathrm{~S}$ (DT-OH) ${ }^{17}$ The addition of peptide 3 and Cys to cells pre-incubated with DT-OH showed strong fluorescence (Fig. 5). To confirm the fluorescence was a result of the $\mathrm{H}_{2} \mathrm{~S}$ released from the peptide, several controls were performed: DT-OH only, DT-OH plus Cys, and DT-OH plus peptide 3 without Cys. Fluorescence was observed in neither

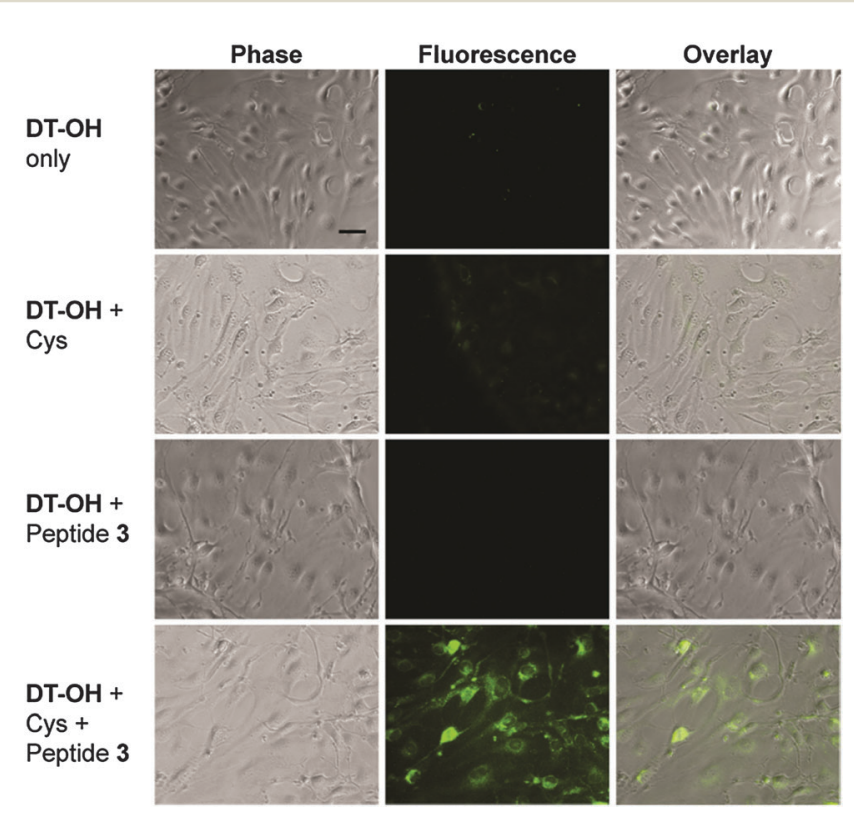

Fig. 5 Phase, fluorescence, and overlay images showing strong fluorescence in endothelial cells preincubated with $\mathrm{H}_{2} \mathrm{~S}$ probe DT-OH $(5 \mu \mathrm{M})$ and then treated with peptide $3(100 \mu \mathrm{M})$ and Cys $(500 \mu \mathrm{M})$. Scale bar $=50 \mu \mathrm{m}$. 
the DT-OH only group nor the DT-OH + peptide 3 group. Weak signal was observed in the DT-OH + Cys group, which we attribute to a previously reported side reaction of similar probes with Cys. ${ }^{3 b}$ In future studies we will assess whether $\mathrm{H}_{2} \mathrm{~S}$ release from peptide 3 occurs in solution followed by diffusion into cells, or whether peptide 3 is internalized into cells before thioltriggered $\mathrm{H}_{2} \mathrm{~S}$ release occurs.

In summary, we have designed and synthesized an $\mathrm{H}_{2} \mathrm{~S}$ releasing peptide that self-assembles into a robust hydrogel. The self-assembly of these peptides was guided primarily though $\beta$-sheet formation with a possible minor contribution from aromatic stacking interactions. Moreover, this peptide demonstrates that the aromatic component of self-assembling aromatic peptide amphiphiles can be designed to be both a structural unit as well as a reactive functional unit that decomposes to release a bioactive small molecule. These results also suggest that such gels may have therapeutic potential for localized $\mathrm{H}_{2} \mathrm{~S}$ delivery. Investigations are currently underway in our laboratory to further explore the self-assembled structure of these peptides and to evaluate their applications as therapeutic $\mathrm{H}_{2} \mathrm{~S}$-releasing materials.

\section{Notes and references}

1 (a) C. Szabo, Nat. Rev. Drug Discovery, 2007, 6, 917-935; (b) H. Kimura, Antioxid. Redox Signaling, 2009, 12, 1111-1123; (c) R. Wang, Physiol. Rev., 2012, 92, 791-896.

2 (a) N. Shibuya, M. Tanaka, M. Yoshida, Y. Ogasawara, T. Togawa, K. Ishii and H. Kimura, Antioxid. Redox Signaling, 2009, 11, 703-714; (b) A. Papapetropoulos, A. Pyriochou, Z. Altaany, G. Yang, A. Marazioti, Z. Zhou, M. G. Jeschke, L. K. Branski, D. N. Herndon, R. Wang and C. Szabó, Proc. Natl. Acad. Sci. U. S. A., 2009, 106, 21972-21977; (c) J. W. Calvert, W. A. Coetzee and D. J. Lefer, Antioxid. Redox Signaling, 2010, 12, 1203-1217; (d) K. Kashfi and K. R. Olson, Biochem. Pharmacol., 2013, 85, 689-703; (e) B. D. Paul, J. I. Sbodio, R. Xu, M. S. Vandiver, J. Y. Cha, A. M. Snowman and S. H. Snyder, Nature, 2014, 509, 96-100; $(f)$ N. Shibuya, S. Koike, M. Tanaka, M. Ishigami-Yuasa, Y. Kimura, Y. Ogasawara, K. Fukui, N. Nagahara and H. Kimura, Nat. Commun., 2013, 4, 1366.

3 (a) A. R. Lippert, E. J. New and C. J. Chang, J. Am. Chem. Soc., 2011, 133, 10078-10080; (b) L. A. Montoya and M. D. Pluth, Chem. Commun., 2012, 48, 4767-4769; (c) B. Peng, W. Chen, C. Liu, E. W. Rosser, A. Pacheco, Y. Zhao, H. C. Aguilar and M. Xian, Chem. - Eur. J., 2014, 20, 1010-1016; (d) X. Wang, J. Sun, W. H. Zhang, X. X. Ma, J. Z. Lv and B. Tang, Chem. Sci., 2013, 4, 2551-2556; (e) J. Cao, R. Lopez, J. M. Thacker, J. Y. Moon, C. Jiang, S. N. S. Morris, J. H. Bauer, P. Tao, R. P. Mason and A. R. Lippert, Chem. Sci., 2015, 6, 1979-1985.

4 (a) Y. Zhao, H. Wang and M. Xian, J. Am. Chem. Soc., 2010, 133, 15-17; (b) Z. M. Zhou, M. V. Rekowski, C. Coletta, C. Szabo,
M. Bucci, G. Cirino, S. Topouzis, A. Papapetropoulos and A. Giannis, Bioorg. Med. Chem., 2012, 20, 2675-2678; (c) T. Roger, F. Raynaud, F. Bouillaud, C. Ransy, S. Simonet, C. Crespo, M. P. Bourguignon, N. Villeneuve, J. P. Vilaine, I. Artaud and E. Galardon, ChemBioChem, 2013, 14, 2268-2271; (d) A. Martelli, L. Testai, V. Citi, A. Marino, I. Pugliesi, E. Barresi, G. Nesi, S. Rapposelli, S. Taliani, F. Da Settimo, M. C. Breschi and V. Calderone, ACS Med. Chem. Lett., 2013, 4, 904-908; (e) J. C. Foster, C. R. Powell, S. C. Radzinski and J. B. Matson, Org. Lett., 2014, 16, 1558-1561.

5 (a) J. C. Foster and J. B. Matson, Macromolecules, 2014, 47, 5089-5095; (b) U. Hasegawa and A. J. van der Vlies, Bioconjugate Chem., 2014, 25, 1290-1300.

6 (a) P. G. Parzuchowski, M. C. Frost and M. E. Meyerhoff, J. Am. Chem. Soc., 2002, 124, 12182-12191; (b) N. A. Stasko and M. H. Schoenfisch, J. Am. Chem. Soc., 2006, 128, 8265-8271; (c) M. R. Kapadia, L. W. Chow, N. D. Tsihlis, S. S. Ahanchi, J. W. Eng, J. Murar, J. Martinez, D. A. Popowich, Q. Jiang, J. A. Hrabie, J. E. Saavedra, L. K. Keefer, J. F. Hulvat, S. I. Stupp and M. R. Kibbe, J. Vasc. Surg., 2008, 47, 173-182.

7 A. W. Carpenter and M. H. Schoenfisch, Chem. Soc. Rev., 2012, 41, $3742-3752$.

8 (a) U. Hasegawa, A. J. van der Vlies, E. Simeoni, C. Wandrey and J. A. Hubbell, J. Am. Chem. Soc., 2010, 132, 18273-18280; (b) N. E. Bruckmann, M. Wahl, G. J. Reiss, M. Kohns, W. Watjen and P. C. Kunz, Eur. J. Inorg. Chem., 2011, 4571-4577; (c) J. B. Matson, M. J. Webber, V. K. Tamboli, B. Weber and S. I. Stupp, Soft Matter, 2012, 8, 6689-6692; (d) A. E. Pierri, P. J. Huang, J. V. Garcia, J. G. Stanfill, M. Chui, G. Wu, N. Zheng and P. C. Ford, Chem. Commun., 2015, 51, 2072-2075.

9 P. K. Allan, P. S. Wheatley, D. Aldous, M. I. Mohideen, C. Tang, J. A. Hriljac, I. L. Megson, K. W. Chapman, G. De Weireld, S. Vaesen and R. E. Morris, Dalton Trans., 2012, 41, 4060-4066.

10 (a) S. Zhang, T. Holmes, C. Lockshin and A. Rich, Proc. Natl. Acad. Sci. U. S. A., 1993, 90, 3334-3338; (b) J. D. Hartgerink, E. Beniash and S. I. Stupp, Science, 2001, 294, 1684-1688; (c) D. J. Pochan, J. P. Schneider, J. Kretsinger, B. Ozbas, K. Rajagopal and L. Haines, J. Am. Chem. Soc., 2003, 125, 11802-11803; (d) V. Jayawarna, M. Ali, T. A. Jowitt, A. F. Miller, A. Saiani, J. E. Gough and R. V. Ulijn, Adv. Mater., 2006, 18, 611-614; (e) J. P. Jung, A. K. Nagaraj, E. K. Fox, J. S. Rudra, J. M. Devgun and J. H. Collier, Biomaterials, 2009, 30, 2400-2410.

11 S. Fleming and R. V. Ulijn, Chem. Soc. Rev., 2014, 43, 8150-8177.

12 (a) Y. Zhang, H. Gu, Z. Yang and B. Xu, J. Am. Chem. Soc., 2003, 125, 13680-13681; (b) D. M. Ryan, S. B. Anderson, F. T. Senguen, R. E. Youngman and B. L. Nilsson, Soft Matter, 2010, 6, 475-479; (c) S. Fleming, S. Debnath, P. Frederix, T. Tuttle and R. V. Ulijn, Chem. Commun., 2013, 49, 10587-10589.

13 R. Orbach, L. Adler-Abramovich, S. Zigerson, I. Mironi-Harpaz, D. Seliktar and E. Gazit, Biomacromolecules, 2009, 10, 2646-2651.

14 (a) T. S. Niwa and A. Ogino, J. Mol. Struct.: THEOCHEM, 1997, 419, 155-160; (b) H.-H. Tsai, K. Gunasekaran and R. Nussinov, Structure, 2006, 14, 1059-1072.

15 N. J. Greenfield, Nat. Protoc., 2006, 1, 2876-2890.

16 A. Barth and C. Zscherp, Q. Rev. Biophys., 2002, 35, 369-430.

17 D. T. Shi, D. Zhou, Y. Zang, J. Li, G. R. Chen, T. D. James, X. P. He and H. Tian, Chem. Commun., 2015, 51, 3653-3655. 